\title{
Utrošci energije i radni učinci kombajna za vađenje krumpira
}

\section{Sažetak}

Krumpir se ubraja u jednu od četiriju strateški najvažnijih namirnica u svijetu. U Hrvatskoj se krumpir najviše uzgaja u Slavoniji i Međimurju gdje je posljednjih nekoliko godina prinos u porastu, ali još uvijek značajno ispod prosjeka zapadnoeuropskih zemalja. Neki od glavnih razloga nekonkurentnosti i neisplativosti proizvodnje na hrvatskom tržištu su: visoke cijene repromaterijala i velika ulaganja u modernizaciju mehanizacije. Cilj rad je utvrditi razinu utroška energije i radnih učinaka kombajna za vađenje krumpira. Kako bi se troškovi proizvodnje sveli na minimum potrebna je suvremena mehanizacija koja smanjuje vrijeme rada, a povećava radni učinak i prihode.

U radu su prikazani rezultati terenskog mjerenja utroška energije i radnih učinaka kod različitih izvedbi kombajna za vađenje krumpira. Analizirani su troškovi vađenja krumpira, a oni su se odnosili na troškove goriva i radnika, bez amortizacije strojeva.

Ključne riječi: krumpir, radni učinci kombajna, utrošak goriva, troškovi

\section{Uvod}

Krumpir je jedna od strateških namirnica u prehrani ljudi, a danas je u svijetu po proizvodnji četvrta kultura iza pšenice, kukuruza i riže (Faostat, 2017). Vrlo je kvalitetna namirnica, gotovo da ne sadrži masti, a ima visok sadržaj vitamina C i kalija te sadrži dosta vlakana. Osim u prehrani ljudi krumpir ima vrlo široku primjenu, pa se tako koristi za proizvodnju alkohola, bioetanola, eksploziva, u farmaceutskoj i tekstilnoj industriji, industriji papira i kao stočna hrana (Pospišil, 2010; Krička i sur., 2006).

Krumpir ovisno o uvjetima uzgoja i kultivara, najčešće dosiže visinu do $1 \mathrm{~m}$. Biljka krumpira sastoji se od stabljike koja se razvila iz klice gomolja ili iz pravog sjemena. Može biti zelene ili ljubičaste boje, ovisno o kultivaru. Broj stabljika na matičnom gomolju ovisi o kultivaru i fiziološkoj dobi gomolja. Listovi su neparno perasti i na stabljici su naizmjenično raspoređeni. Cvijet je samooplodan i dvospolan. Cvjetovi se razvijaju u paštitastim cvatovima i mogu biti bijele, svijetlo plave, ljubičaste ili ružičaste boje. Obilnost cvatnje sortna je karakteristika, a dugi dan i srednje temperature stimuliraju cvatnju.

Plod je višesjemena zelena boba u kojoj se formira 100-200 sjemenki. Pravo je sjeme dosad uglavnom služilo u oplemenjivanju, a danas se koristi i za direktnu sjetvu za proizvodnju jestivog krumpira. Stoloni ili podzemne bočne stabljike imaju tendenciju horizontalnog rasta (u tami humka) (Pinturić, 2016).

Gomolj je modificirani dio podzemne stabljike-stolona, glavni je rezervni organ biljke i služi za prezimljenje i reprodukciju. Boja pokožice može biti: bijela, žuta, crvena, plava, ljubičasta dok je boja mesa žuta ili bijela. Klica gomolja sastoji se od vršnog dijela koji čini vršni pup s listićima i od osnovnog dijela koji čine bočni pupovi i izboji, začeci korijena, lenticele i dlačice.

prof.dr. sc. Stjepan Sito, mag.ing,agr., Blanka Palinić, Sveučilište u Zagrebu, Agronomski fakultet, Zavod za mehanizaciju (ssito@agr.hr) mr.sc. Vlado Kušec, Visoko gospodarsko učilište u Križevcima, Križevci

mag. Branko Šket, Natalija Brečko, iniv. dipl. ekon, Šolski centar Šentjur, Šentjur, Republika Slovenija

doc. dr. sc. Vesna Oćić, Sveučilište u Zagrebu, Agronomski fakultet, Zavod menadžment i ruralno poduzetništvo

Vladimir Džaja, dipl. ing. agr., PIK Vinkovci, Vinkovci

Robert Brkić, univ. spec. MBA Agr., Mladena Fiolića 16F, Zagreb 
Korijen je prilično plitak $(40-50 \mathrm{~cm})$, a u rahlim tlima doseže do $1 \mathrm{~m}$. Cijela biljka, osim gomolja je otrovna jer sadrži otrovni alkaloid solanin (Lešić $i$ sur., 2004).

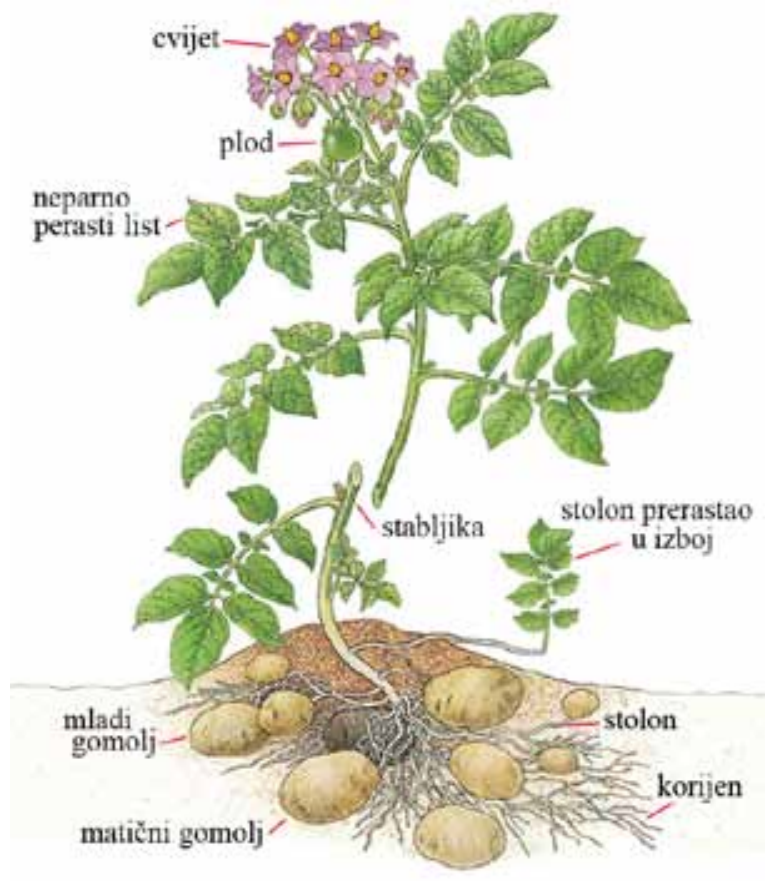

Slika 1. Biljka krumpira

Figure 1. Potato plant

Izvor/Source: Glosarić, 2015

Osim što se krumpir može kuhati, peći i pržiti, danas se na tržištu mogu naći razni polugotovi proizvodi od krumpira: kroketi, njoki, pommes frites i slično (Buturac, 2011). U posljednjih 10 godina tijekom obrade krumpira prženjem velika pozornost se daje praćenju sadržaja akrilamida, koji je potencijalno kancerogen za čovjeka (Čepl $i$ sur., 2014). Ostaci koji ostaju nakon proizvodnje alkohola (votke i akvavita) koriste se za prehranu životinja. Škrob krumpira se koristi kao ljepilo, vezivo, sredstvo za zgušćivanje i punilo u farmaceutskoj, tekstilnoj, drvnoj i papirnoj industriji. Koristi se i za proizvodnju bioetanola, eksploziva, kaučuka, svile, glukoze (Pospišil, 2010).

Uz to što se koristi u dijetalnoj prehrani ima mnoga ljekovita svojstva, pa se tako preporučuje kod probavnih smetnji, proljeva, čireva na dvanaesniku, hemeroida i žučnih kamenaca (Lešić i sur., 2004). U narodnoj medicini kaša od sirovog krumpira se upotrebljava kod reumatizma, upale zglobova, glavobolje, visoke temperature, ozeblina, opeklina. Kora kuhanog krumpira snižava povišeni krvni tlak (http://www.agrico-trade.hr/). Za regulaciju šećera u krvi i problema sa sluznicom želuca upotrebljava se sok svježe iscijeđenog krumpira.

Jedan od najvažnijih čimbenika koji utječe na prinos krumpira je dobra opskrbljenost vodom. Od nicanja do cvatnje krumpir nema velike potrebe za vodom. Krumpir ima najveću potrebu za vodom u fazi cvatnje, tj. u razdoblju od cvatnje do završetka formiranja nadzemne mase. U tom razdoblju se formira oko 75 \% ukupnog prinosa gomolja. Najpovoljnija vlažnost 
tla za proizvodnju krumpira je 60 - 80 \% poljskog vodnog kapaciteta (Pospišil, 2010).

Za dobar rast nasada krumpira treba 400 - 800 mm vode, ovisno o duljini vegetacije i klimatskim uvjetima. Kod gustoće sklopa od 40.000 biljaka po ha to iznosi 100 - $200 \mathrm{~L}$ po biljci u vegetacijskom razdoblju. Navodnjavanje je jako bitno u našim uvjetima u proizvodnji ranog krumpira. Manjak vode očituje se najviše u kontinentalnom području, a ponekad i u obalnom dijelu. Suša smanjuje urod osobito u fazi nalijevanja asimilata u gomolje. Ukupna količina vode u tlu ovisi o ukupnim temperaturama, relativnoj vlazi zraka, evapotranspiraciji, razvijenosti korijenovog sustava, vrsti zemljišta i dr. (Buturac i Bolf, 2000).

\section{Vađenje krumpira}

Ovisno o vremenu berbe, kemijski sastav gomolja je različit. Mladi nezreli gomolji imaju malo suhe tvari i više šećera nego zreli gomolji pa su zato drugačijeg okusa od zrelog mladog krumpira, a pogotovo od starog krumpira. Kada se gomoljima više ne smanjuje ukupna količina šećera smatramo ih „kemijski zrelim”. U praksi se uglavnom ne mjere šećeri nego se zrelost gomolja utvrđuje testom guljenja pokožice pritiskom palca (https://grama.com.hr/klijanjekrumpira-u-skladistima/).

Dva tjedna prije iskopa cima se uništava kemijski (desikantima) ili mehanički (strojevima za kaširanje cime s rotirajućim noževima) (Lešić $i$ sur., 2004). Defolijacija je korisna jer se dobiva jačina pokožice koja je dobra kod skladištenja, a omogućuje i raniju berbu sa manjim oštećenjima gomolja (Verugendhil i sur., 2007). Na manjim površinama iskop se obavlja ručno i vadilicama, a na većim površinama kombajnima na kojima se krumpir uvreća ili odlaže u bunker. U izvađenoj masi treba biti što manje gruda, zemlje, kamenja, ostataka cime, bolesnih i majčinskih gomolja. Dizajn i postavke kombajna utječu na učinkovitost odvajanja gomolja željene veličine i spremanja u bunker sa minimalnim oštećenjima. Loše prilagođeni strojevi u berbi mogu rezultirati štetom na mnogo načina: gomolj se može zdrobiti pod veličinom kotača, izrezati zbog neodgovarajuće dubine vađenja, oguliti ili dobiti modrice prilikom valjanja i odskakanja po valjcima za separaciju. Do značajnih oštećenja (modrica) može doći kod kipanja krumpira u prikolicu, a visinu pada treba svesti na minimum (Verugendhil $i$ sur., 2007). U kontinentalnom području većina sorata za korištenje u jesenskim i zimskim mjesecima se vadi u prvoj polovici rujna (Pospišil, 2010).

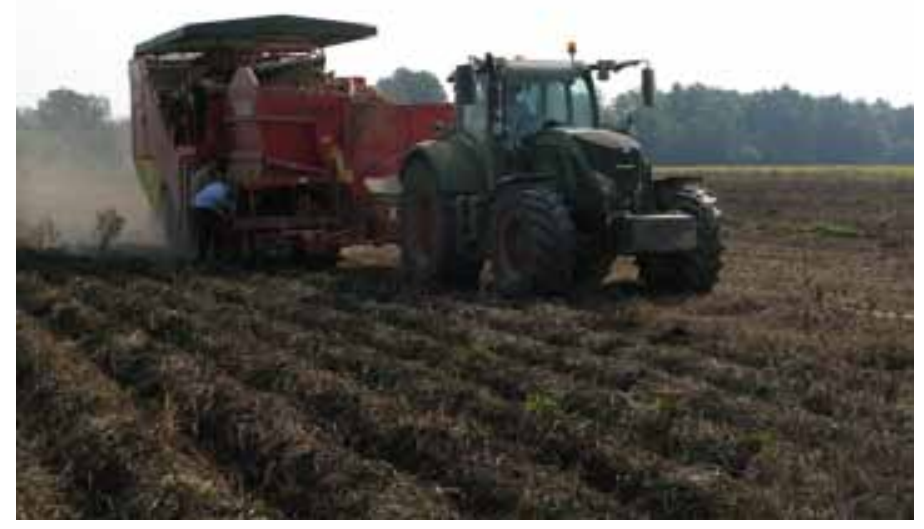

Slika/Figure 2. Vađenje krumpira/ Potato harvesting Izvor/Source: Sito, 2015 


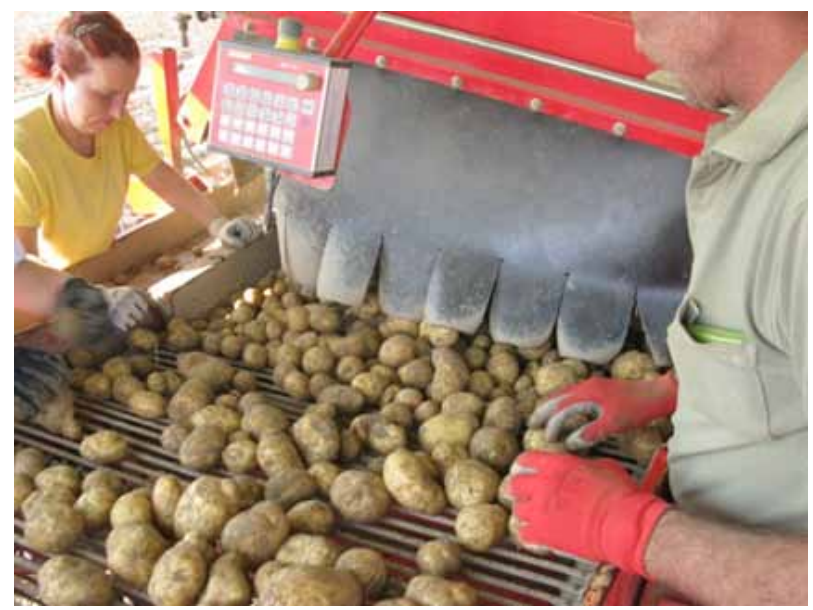

Slika/Figure 3. Sortiranje krumpira/ Sorting potatoes Izvor/Source: Palinić, 2015

Najvažniji stroj u poljoprivrednoj proizvodnji je traktor te je poljoprivredna proizvodnja u današnje vrijeme bez njega nezamisliva. Da bi traktor bio ekonomski isplativ treba zadovoljiti neke čimbenike kao što su: veličina zemljišta (parcele) koje se obrađuje, kulture koja se uzgaja i potrebe za transportom. Ti čimbenici su bitni kod odabira karakteristika traktora (snage traktora, vučne sposobnosti, opreme i mase), da bi se nabavio traktor koji će sve potrebne radne operacije obaviti sa optimalnom potrošnjom goriva te tako smanjiti troškove proizvodnje i ostvariti veći dohodak odnosno omogućiti racionalno iskorištavanje uloženih sredstva.

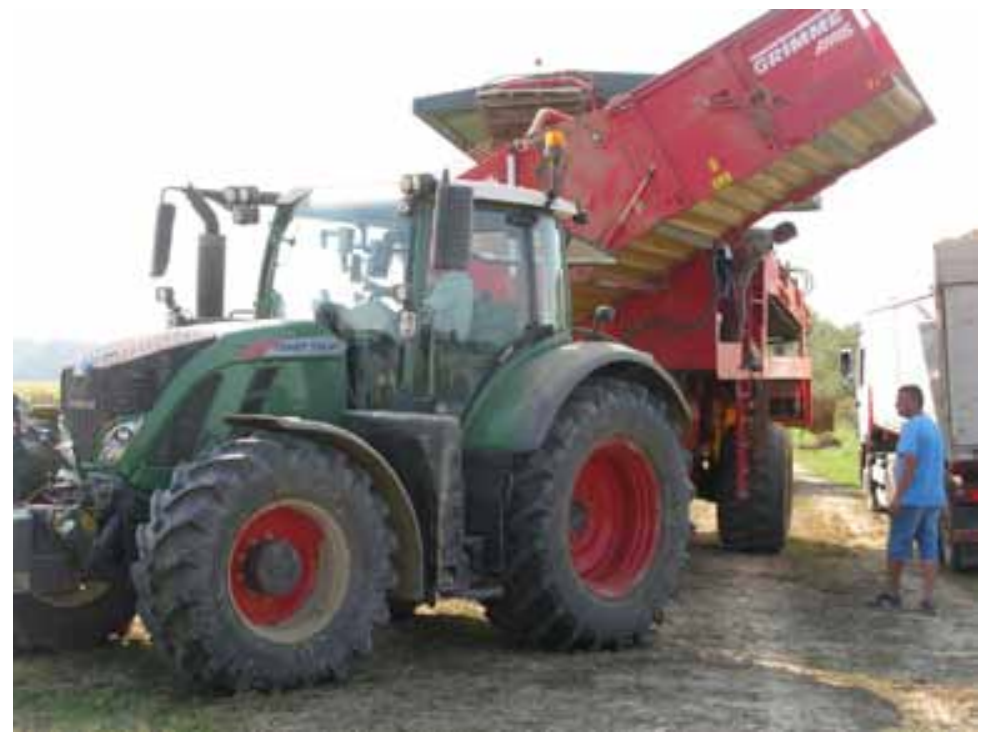

Slika/Figure 4. Traktor Fendt 714 Vario/Tractor Fendt 714 Vario Izvor/Source: Palinić, 2015 
Kombajn za krumpir je složeni stroj koji u jednoj radnoj operaciji vadi gomolje, odstranjuje primjese (grude, kamenje, sipku zemlju, ostatke cime, trule gomolje), a očišćene gomolje odlaže u spremnik na stroju ili ih izravno prebacuje u prikolicu koju vuče drugi traktor paralelno s kombajnom (Sito i sur., 2015). Postoje jednoredni i dvoredni kombajni sa protresajućom trakom. Cima i zelena masa im ne stvaraju probleme u berbi. Upotrebom kombajna smanjuje se udio radne snage na 3-8 radnika ovisno da li se radi o jednorednom ili dvorednom kombajnu (Čuljat i Barčić, 1997).

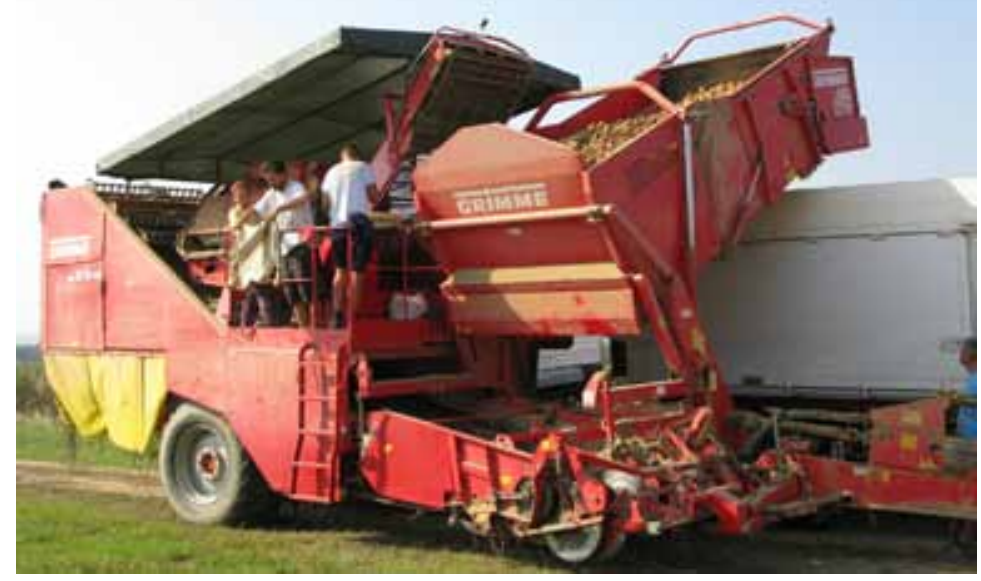

Slika/Figure 5. Kombajn Grimme SE 150-60/Potato harvester Grimme SE 150-60 Izvor/Source: Sito, 2015

\section{Materijali i metode rada}

Mjerenje je provedeno na 7 lokacija u Bjelovarsko-bilogorskoj, Međimurskoj i Varaždinskoj županiji. Utrošak goriva se mjerio volumetrijskom metodom, a radni učinci prilikom vađenja gomolja su izračunati na osnovu dužine parcele i vremena koje je potrebno da stroj prođe cijeli prohod. Izvađeni gomolji su bili izvagani.

Od industrijskog krumpira najviše se uzgajaju sorte Lady Claire i Opal, a od konzumnog (merkantilonog) krumpira sorta Colombo.

Tablica 1. Izvedbe traktora i kombajna na pokusnom mjerenju

Table 1. Models of tractors and potato harvesters used in trails

\begin{tabular}{|c|c|c|c|c|c|c|c|}
\hline $\begin{array}{c}\text { Proizvođač/ } \\
\text { Producer }\end{array}$ & 1 & 2 & 3 & 4 & 5 & 6 & 7 \\
\hline $\begin{array}{l}\text { Traktor/ } \\
\text { Tractor }\end{array}$ & $\begin{array}{c}\text { Fendt } 714 \\
\text { Vario }\end{array}$ & $\begin{array}{c}\text { John Deere } \\
6430 \\
\text { Premium }\end{array}$ & $\begin{array}{l}\text { Fendt } 311 \\
\text { LSA Farmer }\end{array}$ & Fendt 311 LS & $\begin{array}{c}\text { Fendt } 307 \\
\text { Farmer C }\end{array}$ & $\begin{array}{c}\text { John Deere } \\
6400\end{array}$ & $\begin{array}{c}\text { Hürlimann } \\
\text { XA } 86\end{array}$ \\
\hline $\begin{array}{l}\text { Kombajn/ } \\
\text { Harvester }\end{array}$ & $\begin{array}{c}\text { Grimme SE } \\
150-60\end{array}$ & $\begin{array}{c}\text { Grimme } \\
75-30\end{array}$ & $\begin{array}{c}\text { Grimme SR } \\
80-40\end{array}$ & $\begin{array}{c}\text { Vilmaus } \\
75-20\end{array}$ & $\begin{array}{c}\text { Grimme SE } \\
85-55\end{array}$ & Imac 75-30 & $\begin{array}{c}\text { Grimme SS } \\
140-40\end{array}$ \\
\hline
\end{tabular}

U tablici 1. prikazane su izvedbe traktora i kombajna koji su se koristili tijekom terenskog mjerenja utroška energije-goriva i radnih učinaka prilikom vađenja krumpira. 
Tablica 2. Tehničke karakteristike traktora na pokusnim lokacijama

Table 2. Technical specifications of tractors used at experimental locations

\begin{tabular}{|c|c|c|c|c|c|c|c|}
\hline $\begin{array}{c}\text { Tip traktora/Type } \\
\text { of tractor }\end{array}$ & $\begin{array}{c}\text { Fendt } 714 \\
\text { Vario }\end{array}$ & $\begin{array}{c}\text { John Deere } \\
6430 \\
\text { Premium }\end{array}$ & $\begin{array}{l}\text { Fendt } 311 \\
\text { LSA Farmer }\end{array}$ & $\begin{array}{c}\text { Fendt } 311 \\
\text { LS }\end{array}$ & $\begin{array}{c}\text { Fendt } 307 \\
\text { Farmer C }\end{array}$ & $\begin{array}{c}\text { John Deere } \\
6400\end{array}$ & $\begin{array}{l}\text { Hürlimann } \\
\quad \text { XA } 86\end{array}$ \\
\hline Snaga/Force (kW) & 107 & 103 & 81 & 74 & 55 & 73 & 54,5 \\
\hline $\begin{array}{c}\text { Hidraulika/ } \\
\text { Hydraulics }\left(\mathrm{L} \mathrm{min}^{-1}\right)\end{array}$ & 109 & 110 & 72 & 70 & 180 & 61,5 & 54 \\
\hline $\begin{array}{c}\text { Specifična } \\
\text { potrošnja/ } \\
\text { Specific } \\
\text { consumption (g/ } \\
\text { kWh) }\end{array}$ & 203 & 292 & 217 & 250 & 207 & 200 & 196 \\
\hline Masa/weight 1 & 7.735 & 5.545 & 5.430 & 4.690 & 3.800 & 4.680 & 3.500 \\
\hline Masa/weight 2 & 12.500 & 9.000 & 7.500 & 6.000 & 6.000 & 7.500 & 5.400 \\
\hline
\end{tabular}

Raspon snage motora traktora se kretao od 55 pa do 107 kW ovisno o tome da li vuče i pogoni jednoredni ili dvoredni kombajn. Specifična potrošnja goriva se kretala od 196 (Hurliman XA 86) pa sve do $292 \mathrm{~g} / \mathrm{kWh}$ (John Deere 6430 Premium) dok se masa traktora kretala od 3.500 pa do $7.735 \mathrm{~kg}$ (Tablica 2).

\section{Rezultati i rasprava}

U Tablici 3. prikazane su vrijednosti utroška goriva koje su jako varirale i kretale se od 16,1 L/h kod Fendta 714 (dvoredni kombajn) do 5,2 L/h kod Johan Deere 6400 (jednoredni kombajn) u optimalnim uvjetima tla i usjeva. Utrošak goriva u nepovoljnim uvjetima tla i nasada (raskvašeno tlo, blato) raste na 27,1 L/h kod kombajna Grimme SE 150-60 dok su se utrošci goriva kod jednorednih kombajna kretali u rasponu od 9,8 do 18,7 L/h (Grafikon 1).

Radni učinci vađenja krumpira u optimalnim uvjetima kod dvorednih kombajna su se kretali od 12,5 do 14,2 t/h, dok su se kod jednorednih učinci vađenja krumpira kretali u rasponu od 4,3 do 7,9 t/h.

Tablica 3. Rezultati istraživanja vađenja krumpira u optimalnim uvjetima

Table 3. Potato harvesting results in optimal conditions

\begin{tabular}{|c|c|c|c|c|c|c|c|}
\hline & $\begin{array}{c}\text { Grimme SE } \\
150-60\end{array}$ & $\begin{array}{l}\text { Grimme } \\
75-30\end{array}$ & $\begin{array}{c}\text { Grimme SR } \\
80-40\end{array}$ & $\begin{array}{c}\text { Vilmaus } \\
75-20\end{array}$ & $\begin{array}{c}\text { Grimme SE } \\
\quad 85-55\end{array}$ & Imac 75-30 & $\begin{array}{c}\text { Grimme SE } \\
140-40\end{array}$ \\
\hline $\begin{array}{l}\text { Učinak/ } \\
\text { Effect (t/h) }\end{array}$ & 14,2 & 7,9 & 6,1 & 5,8 & 6,5 & 4,3 & 12,5 \\
\hline $\begin{array}{c}\text { Učinak/ } \\
\text { Effect (t/dan) }\end{array}$ & 125 & 62 & 48 & 45 & 52 & 51 & 105 \\
\hline $\begin{array}{c}\text { Utrošak goriva/ } \\
\text { Fuel consumption } \\
(\mathrm{L} / \mathrm{h})\end{array}$ & 16,1 & 10,3 & 12,2 & 12,4 & 13,4 & 5,2 & 7,2 \\
\hline $\begin{array}{c}\text { Prinosi/Yields t/ } \\
\text { ha }\end{array}$ & 45 & 45 & 42 & 38 & 60 & 58 & 55 \\
\hline $\begin{array}{l}\text { Učinak/Effect (ha/ } \\
\text { dan) }\end{array}$ & 2,8 & 1,4 & 1,2 & 1,2 & 0,9 & 0,9 & 1,9 \\
\hline
\end{tabular}


glasnik zaštite bilja $\underset{\text { godina }}{61}$

Grafikon/Graph 1. Utrošak goriva u optimalnim i teškim uvjetima vađenja krumpira/ Fuel consumption in optimum and heavy potato harvesting conditions, (L/h)

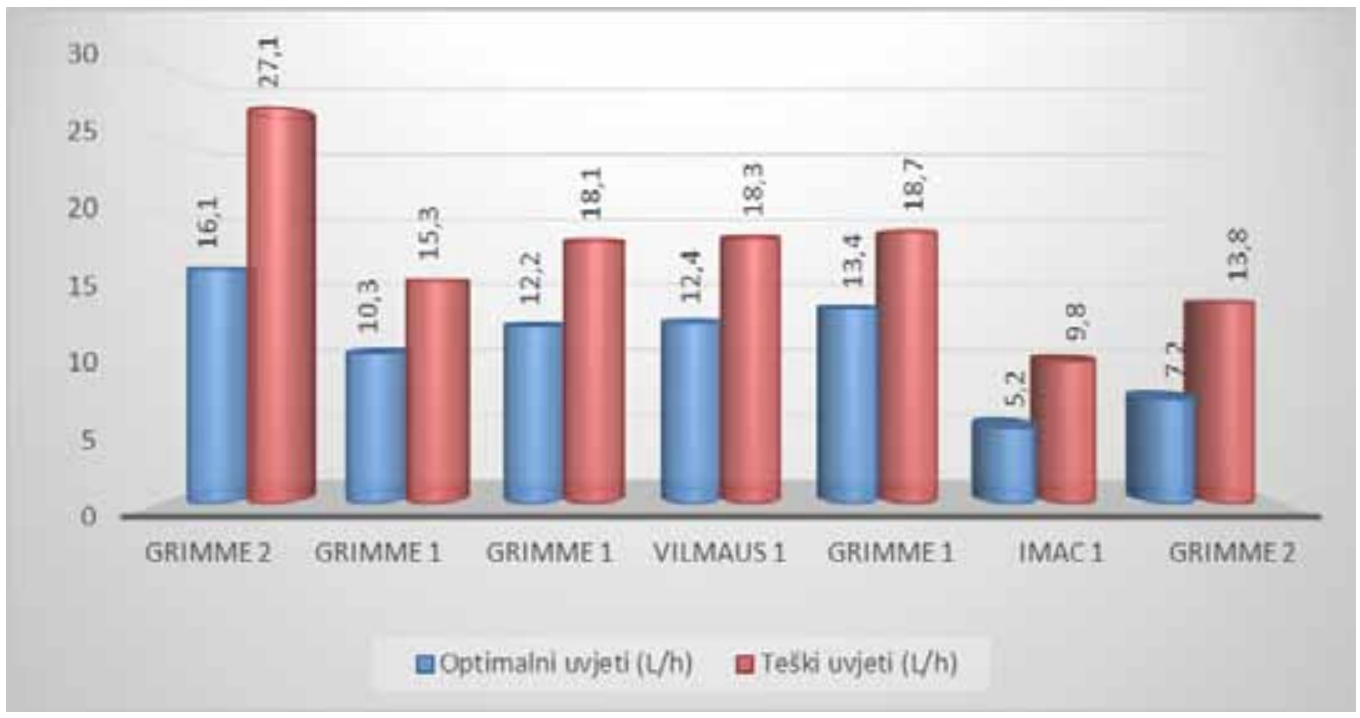

Utrošak goriva se kretao od 1,11 L/t izvađenog krumpira kod dvorednog kombajna pa do 2,14 L/t kod jednorednih kombajna (Grafikon 2.).

Grafikon/Graph 2. Utrošak goriva u optimalnim i teškim uvjetima vađenja krumpira/Fuel consumption in optimum and heavy potato harvesting conditions $(\mathrm{L} / \mathrm{t})$

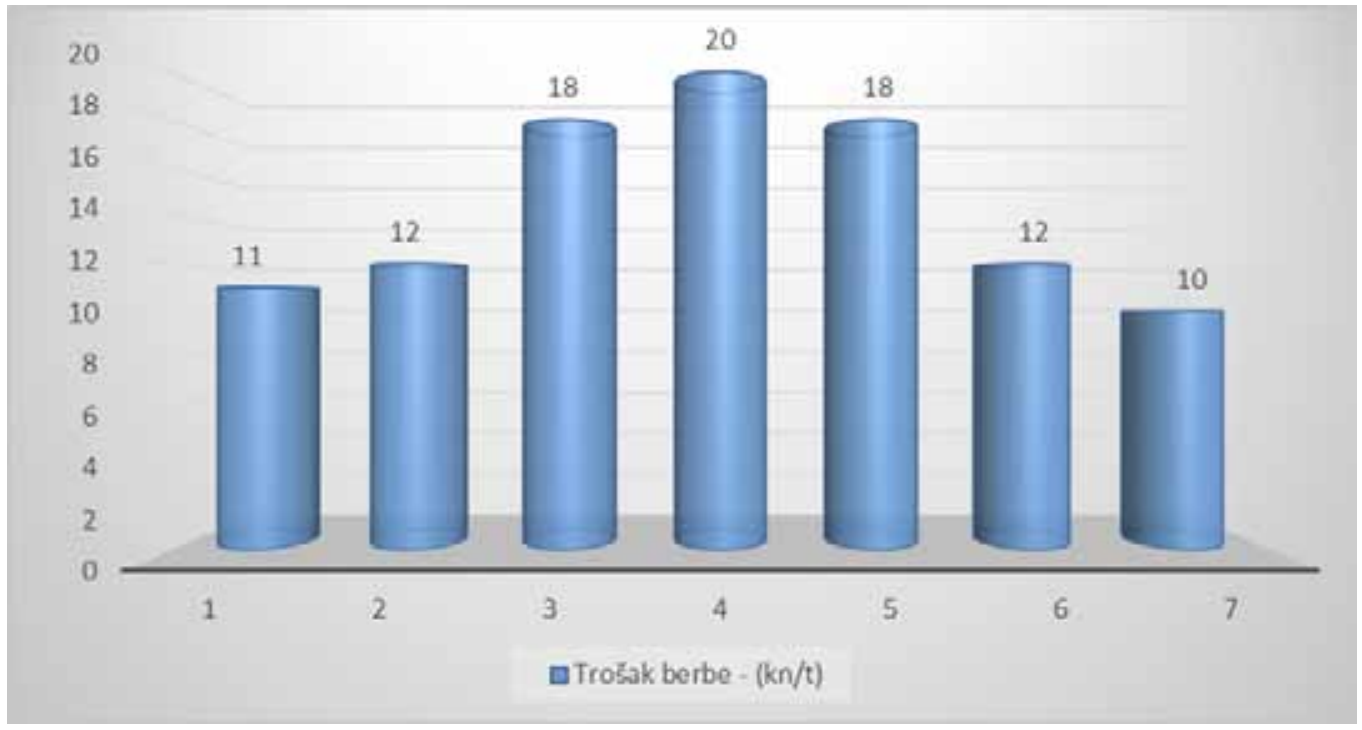


Troškovi po izvađenoj toni krumpira su od 10 kn/t kod dvorednih kombajna, pa do 20 kn/t kod jednorednih kombajna (Grafikon 3).

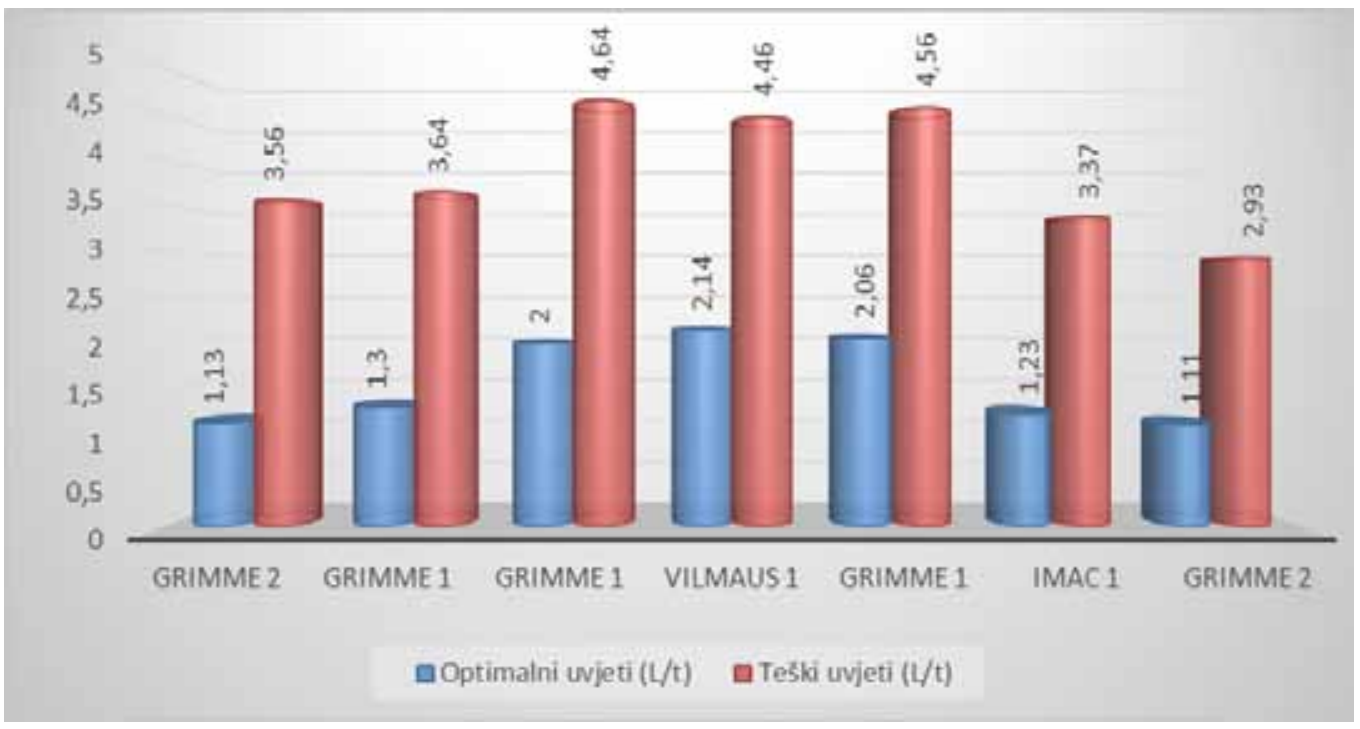

Grafikon/Graph 3. Prosječni trošak berbe-vađenja/ Average cost of harvesting (kn/t) Podaci na x-osi/Data on x-axis; (Tablica 1/Table 1.)

Prilikom vađenja krumpira potrebno je 3-5 radnika, ovisno da li je kombajn jednoredan ili dvoredan. Satnica je 20 kn po satu, a radi se 8 sati na dan. Tako je trošak vađenja krumpira kod jednorednih kombajna bio od 659 kn po danu do 971 kn danu, a kod dvorednih kombajna se kretao od 1.048 do 1.354 kn po danu.

Prihodi po hektaru su se kretali u rasponu od 51.300 pa do $90.000 \mathrm{kn} / \mathrm{ha}$. Razlog tome su u pravilu veći prinosi i prosječna cijena konzumnog (merkantilnog) krumpira u odnosu na industrijski krumpir, te različita prodajna cijena za merkantilni i krumpir za preradu (Savjetodavna služba RH, 2012).

\section{Zaključak}

Cilj rada bio je utvrditi razinu utroška energije i radnih učinaka kod različitih izvedbi kombajna za vađenje krumpira.

Utvrđena je razlika u urodu industrijskog u odnosu na konzumni krumpir. Tako su se urodi industrijskog krumpira kretali od 38-45 t/ha dok su urodi konzumnog krumpira iznosili su 5560 t/ha. Utrošak goriva u optimalnim uvjetima tla i nasada se kretao od 5,2 do 13,4 L/h kod jednorednih kombajna dok je kod dvorednog kombajna utrošak bio 16,1 L/h. Učinak berbe kod jednorednih kombajna je bio od 4,3 do 7,9 tona po satu, a kod dvorednog kombajna 14,2 tona po satu. Utrošak goriva po toni krumpira jednorednim kombajnima se kretao od 1,23 do 2,14 L/t, dok je kod dvorednog kombajna utrošak 1,11 L/t.

U nepovoljnim uvjetima utrošak goriva značajno raste pa je tako utrošak goriva kod jednorednih kombajna od 9,8 do 18,7 L/h, a kod dvorednog potrošnja raste do $27,1 \mathrm{~L} / \mathrm{h}$.

Povećanje potrošnje goriva, u teškim (nepovoljnim) uvjetima rada, po toni krumpira kod jednorednih kombajna kreće se od 3,37 do 4,64 L/t, dok je kod dvorednog kombajna 3,56 L/t. 
Na racionalnu potrošnju goriva i maksimalne radne učinke berbe utječu: uvjeti tla prilikom vađenja, stanje nasada, podešenost stroja, prilagođenost traktora i kombajna, oblik i dužina parcele i iskustvo rukovatelja (traktorista).

Proizvodni troškovi $1 \mathrm{~kg}$ krumpira su se kretali od 0,70 pa do 1,10 kn. Značajna razlika u trošku proizvodnje, posebno kod velikih proizvođača, se može objasniti činjenicom da se repromaterijal (sjeme, zaštitna sredstva, gnojiva i dr.) nabavom u većim količinama za vlastite potrebe i za potrebe njihovih kooperanata postižu veliki popusti (rabati). Na proizvodne troškove značajno utječu i radni uvjeti te primjena suvremene mehanizacije u uzgoju i vađenju gomolja krumpira.

\title{
Napomena
}

Rad je izvod iz diplomskog rada studentice mag. ing. agr. Blanke Palinić diplomskog studija Hortikultura-Povrćarstvo

\section{Literatura}

Buturac, I. (2011) Moderno trženje krumpira. Glasnik zaštite bilja, 34 (5), 50-57.

Buturac, I., Bolf, M. (2000). Proizvodnja krumpira. Zagreb: Hrvatski zadružni savez, Biblioteka „Zadružni poduzetnički savjetnik",

Cepl, J., Kasal, P., Svobodova, A. (2015) Tehnology of potato weed management under conditions of low input systems. Proceedings of the 43th International Symposium on Agricultural Engineering, Opatija, 787-795.

Čepl, J., Kasal, P., Svobodova, A., Hajslova, J., Bartackova, V. (2014) Potato processing into fried products - an effect of growing tehnology on acrylamide precursor content in potato tubers. Proceedings of the 42th International Symposium on Agricultural Engineering, Opatija, 315-325.

Culjat, M., Barčić, J. (1997) Poljoprivredni kombajni, Osijek: Poljoprivredni institut.

Faostat (2017) Database - Crops, http://www.fao.org/faostat/en/\#data/QC (1.12.2017)

Glosarić, M. (2015) Utjecaj sorte i brzine kretanja na kakvoću rada uređaja za vađenje krumpira. Završni rad. Križevci: Visoko gospodarsko učilište u Križevcima

Krička, T., Voća, N., Jukić, Ž., Janušić, V., Matin, A. (2006) Iskustva u proizvodnji i iskorištavanju obnovljivih izvora energije u Europskoj uniji. Krmiva : Časopis o hranidbi životinja, proizvodnji i tehnologiji krme, 48 (1), $49-54$.

Lešić, R., Borošić, J., Buturac, I., Herak-Ćustić, M., Poljak, M., Romić, D. (2004) Povrćarstvo, 2. izdanje. Čakovec: Zrinski. Pinturić, M. (2016) Utvrđivanje vrste Globodera rostochiensis (Wollenweber, 1923) Behrens, 1975 u uzorcima tla iz lokaliteta Belica. Diplomski rad. Zagreb: Sveučilište u Zagrebu Agronomski fakultet

Pospišil, A. (2010) Ratarstvo, 1. dio. Čakovec: Zrinski.

Savjetodavna služba RH (2012) Model kalkulacija pokrića varijabilnih troškova poljoprivredne proizvodnje za 2012. godinu. dostupno na: http://www.savjetodavna.hr/savjeti/306/360/model-kalkulacija-pokrica-varijabilnih-troskovapoljoprivredne-proizvodnje-za-2012-godinu/ (1.12.2017.)

Sito, S., Džaja, V., Kušec, V., Ciler, K., Palinić, B., Glogovšek, T. (2015) Suvremena tehnika u proizvodnji krumpira. Glasnik zaštite bilja, 38 (5), 70-84.

Verugendhil, D., Bradshaw, J., Gebhardt, C., Govers, F., MacKeron, D.K.L., Taylor, M.A., Ross, H.A. (2007) Potato Biology and Biotehnology advances and perspectives. Laboratory of Plant Physhiology, Wageningen University and Research Centre, Wageningen, The Netherlands. www.agrico-trade.hr/okrumpiru.html - pristupljeno 3.5.2016.

\section{Energy consumption and area capacity of potato harvester}

\begin{abstract}
Although the potato is one of four strategically most important foods in the world, Croatia still does not produce enough potato for its own needs. In Croatia, the potato is mostly grown in Slavonia and Medimurje region where in the last few years the yield is rising, but still well below the average for Western European countries. Some of the main reasons for the lack of competitiveness and the unprofitability of the Croatian market are: high prices of raw materials and large investments in modern equipment. The aim of the paper is to determine the level of energy consumption and work performance of potato harvesters. To reduce costs to minimum it is necessary to invest in modern machinery that reduces the operating time, and increase productivity and revenue.

Keywords: potato, working efficient of potato harvester, fuel consumption, costs
\end{abstract}

